\begin{tabular}{|c|cc|c|}
\hline PORT SAID ENGINEERING RESEARCH JOURNAL & Faculty of Engineering - Port Said University \\
No. 2 & September 2020 & pp. 1-9 \\
(Architectural Engineering)
\end{tabular}

\title{
The Relation Between Alexander's Fifteen Fundamental Properties and Sustainability in Office Buildings
}

\author{
Osama M. Abo eleinen ${ }^{1}$, Dina S. Noaman ${ }^{2}$, Mayar El-Sayed Moeat ${ }^{3}$ \\ Received: 10 March 2020; Accepted: 28 June 2020
}

\begin{abstract} alexandrine rule and achieving sustainability of the building.

\section{INTRODUCTION}

As an impact of the great development in the architecture field, sustainability issues are a concern among the architects not only in a physical way but also in a psychological aspect [1]. Building adaptivity considered a main pillar in sustainability ethics in physical and psychological aspects. New techniques and methods developed to adapt the building physically without considering the final appearance of the buildings. These techniques led to creating various forms that raise the feeling of anxiety for its occupants. Christopher Alexander is an architect and mathematician investigated the phenomena that some buildings raise anxiety and others don't. His investigation resulted in great findings of how to design buildings that are psychologically adaptive to human being's needs. Alexander published his findings in a four-volume book named the nature of order.

In his book, he describes how vernacular architects built buildings that is adaptive on both psychological and physical perspective in a very easy way [2].
\end{abstract}

The shading system plays a significant role in building envelope design. Also, the shading system geometry controls both the appearance and performance of the building. On the other hand, Christopher alexander -theorist and architect- developed a theory about the impact of certain geometrical rules on human beings' psychological needs. Alexander found that these rules have a great impact in removing anxiety and creating a comfortable feeling to the building occupants. Therefore, this paper investigates the following points: first, the external shading, second, the alexandrine rules and theory and third the relationship between alexandrine geometric rules and building sustainability. The investigation is done by analyzing 30 case studies that certified sustainable. The analysis resulted that there is a certain relation between using each of the fifteen

Keywords: Alexander's Fifteen Properties, Shading, Sustainability, Office Building.

\footnotetext{
${ }^{I}$ Architecture and Urban Planning Department, Faculty of Engineering, Port Said University, Egypt, email: Aboeinen@ hotmail.com

${ }^{2}$ Architecture and Urban Planning Department, Faculty of Engineering, Port Said University, Egypt, email: dinasamy87@gmail.com

${ }^{3}$ Architecture and Urban Planning Department, Faculty of Engineering, Mansoura University, Mansoura, Egypt, corresponding author, email: . mayar.moeat2@gmail.com
}

DOI: $10.21608 /$ pserj.2020.25409.1035
It seems like that vernacular architects have innate design method in their DNA. This method enables them to create adaptive buildings, And so alexander called this phenomenon the phenomena of life.

Through his investigation alexander and his colleagues found that there are certain geometric rules. These rules repeatedly appear in vernacular architecture and don't follow a certain style. Alexander noted that the use of his discovered fifteen properties would help in removing anxiety and creating psychological comfort in designing adaptive buildings [2], [3]. On the other hand in designing building envelopes there are several components the architects have to deal with. These components such as external walls, glazing, roofs, and external shading. The external shading plays a great role among other envelope components due to its effect on the final appearance of the building. the shading system also has a huge effect on indoor thermal performance [4]. As a result, this paper investigates the relation of using the alexandrine fundamental properties in the design of the shading system and building sustainability.

\section{EXTERNAL SHADING}

External shading plays an important role in building's thermal performance and aesthetics, it also provides the building with a "sculptured skin" [4]. Shading devices improve the indoor thermal conditions for ventilated and non-ventilated buildings[5]. Several studies show the effect of shading devices on the energy consumption of the building such as a study by Wong lee in 2007 on the effect of using shading devices in Singapore for east-west oriented facades. The study showed that 2.62\%:3.24\% of energy cooling loads can be reduced by applying a horizontal shading device with $30 \mathrm{~cm}$ in depth [6],[7]. When the depth 
of the shading device is increased to $60 \mathrm{~cm}, 5.85 \%: 7.06 \%$ of the cooling loads are decreased. Extending the depth of the shading device to $90 \mathrm{~cm}$ the cooling loads is decreased by $8.27 \%: 10.13 \%$ [6], Another study by Wong nyuk about the effect of horizontal and vertical shading in Singapore found that by using horizontal shading devices the temperature decreased by $.6^{\circ} \mathrm{C}$ to $.88^{\circ} \mathrm{C}$, moreover, when using vertical shading devices the indoor temperature is decreased by $.98{ }^{\circ} \mathrm{C}$ [4], [8]. Another study by yang and Hwang in 1999 about the impact of external shading on energy saving in Taiwan, the study found that external shading can save an average of $25 \%$ from the cooling loads [4], [9]. A study by Palermo in 2010 demonstrates the effect of shading devices on energy consumption for Cairo, Lisbon, and Madrid while maintaining indoor operative temperature in acceptable range according to iso7730. The study found that by comparing the energy consumption before and after implementing the shading devices found that the total energy saving is from $55 \%$ to $60 \%$ in Cairo,38\%: $50 \%$ in Lisbon and 3\%: 9\% in Madrid [5]. Regarding these previous studies, the shading system has an effective impact on reducing the indoor temperature, moreover a significant contribution to achieving building sustainability.

\section{ALEXANDER'S FIFTEEN FUNDAMENTAL PROPERTIES}

For more than 60 years of investigation, The architect and mathematician Christopher Alexander managed to answer the question of why some buildings tend to have life and remove anxiety from its users and some other buildings don't. the phenomenon of feeling relaxed in a place or feeling comfortable to look to certain objects is called the phenomenon of life [10]. The phenomenon of life is created naturally by the vernacular architects and exists extensively in vernacular architecture. The vernacular architecture has unique form language properties with a decent level of complexity which enabled the phenomenon of life to occur $[1,3]$. Alexander analyzed more than a thousand buildings that have a great psychological impact on its users, alexander and his colleagues discovered fifteen rules that appear over and over in these buildings and described the buildings that possess these rules as it possesses life [11] .these rules are very related and derived from nature that it can be applied to any man-made object to give it life.also, using these rules in the design process helps in creating more adaptive and sustainable designs [3], [12]. The vernacular architects used these rules without knowing it, and as a result, the vernacular architecture has various buildings that are full of these rules in their designs.these rules are called fifteen fundamental properties and described in the following points [11]:

- Levels of scale: it means that the centers of the whole tend to have a beautiful range of well-marked levels with definite jumps, not too large or not too small.

- Strong centers: it means that the relation between the collections of centers that appears as a whole is strong through having a center of attention or focus and would be noticed id a center is missing.

- Thick boundaries: the boundary of each center should enclose, separate, connect the centers in various geometric ways, good boundaries need to be of the same order of magnitude as the center being bounded.

- Alternating repetition:

it is the rhythm that is repeated to appear strongly. The center needs secondary centers repeating between primary ones. Repeating without alternating doesn't enhance the living character of centers.

- Positive space: it is considered the shape that is made of the adjacent shape of the center, it should be a definite shape not just the leftover space or be an undefined shape.

- Good shape: each center is made of multi coherent centers the good shape tends to have symmetry, create a positive space, distinct from what's around, compact, has an enclosure and give the feeling that it is closed and complete.

- Local symmetries: the symmetry of each shape of a center not the symmetry of the whole.

- Deep interlock and ambiguity: the centers tend to have a hooking effect, like a spatial ambiguity, an ambiguous relationship that connects the centers.

- Contrast: it is the differentiation that creates life, the contrast between rough and smooth, dark and light, solid and void.

- Gradients: it is the graded variation in scale between centers and each other in a certain direction.

- Roughness: it is the slight difference of repeated units in size, spacing in the absence of artificial mimics.

- Echoes: it is the resampling of an element with different sizes and angles through the whole design with maintaining the balance of angels and proportions. All other design elements are derived from a single family of shapes.

- The void: it is the presence of a void in the heart of design which is infinite in depth, surrounded and centered with other centers.

- Simplicity and inner calm: Geometric simplicity and purity which is geometrically tangible. Simplicity doesn't automatically generate inner calm, the inner calm occurs when removing every unnecessary object in the design. These rules don't follow a certain style but it should be applied with a proper form language that has a certain level of complexity among its parts.

- Not-separateness: the whole would be so harmonious that melts into its surroundings without giving up its character or personality 


\section{THE THEORY OF CENTERS}

Alexander's fifteen properties describe the relations between the object components. Alexander named the component of each object as "center", each center has the properties that define it as a unique center [11]. the centers strengthen each other to form a "whole".the whole is the sum of centers that have certain configurations and relations to each other on different hierarchy levels. each center consists of subcenters and so on. the living structure is determined by its strong centers. the centers are sets that often bounded, connected, convex, often symmetrical, differentiated from the space next to them, radiating outward and creating coherence through a centered quality in a space [11]. each center or component gets its life from other centers. The fifteen properties are the rules governing the interaction of centers that helps in creating the life of the center. the life of an object comes from the wholeness, from the system of centers. the degree of life obtained comes from the degree of life of the component centers. The degree of life can be measured by achieving as many as possible from the alexandrine properties. each added rule increases both coherence and the center's degree of life [11].

\section{Methodology}

This paper aims to investigate the relation between the fifteen fundamental properties and the sustainability of the building. The investigation is done by analyzing the shading system design of 30 projects. Each project is certified to be sustainable with international or local certificates such as LEED (Leadership in Energy and Environmental Design), BREEAM(Building Research Establishment Environmental Assessment Method ), Green Star in Australia and DGNB in Germany. The collected case studies see Table2 [13],[16] must have a clear usage of the shading system in controlling solar penetration. The case studies were selected carefully to be the best match for the research topic. The case studies location varies around the world, Australia had the largest part of the sustainability contribution in existing sustainable buildings among the case studies. Each building shading system is analyzed on three levels of relations to determine its degree of life: A) The relation between the shading system as a center and the building outline as a whole b) The relation between shading system units and each other as a representative of the relation between centers, and c) The relation between the components of each shading device Figure 1 and Table 1. The degree of life is calculated according to the achievement percentage of the alexandrine properties among the shading system component.

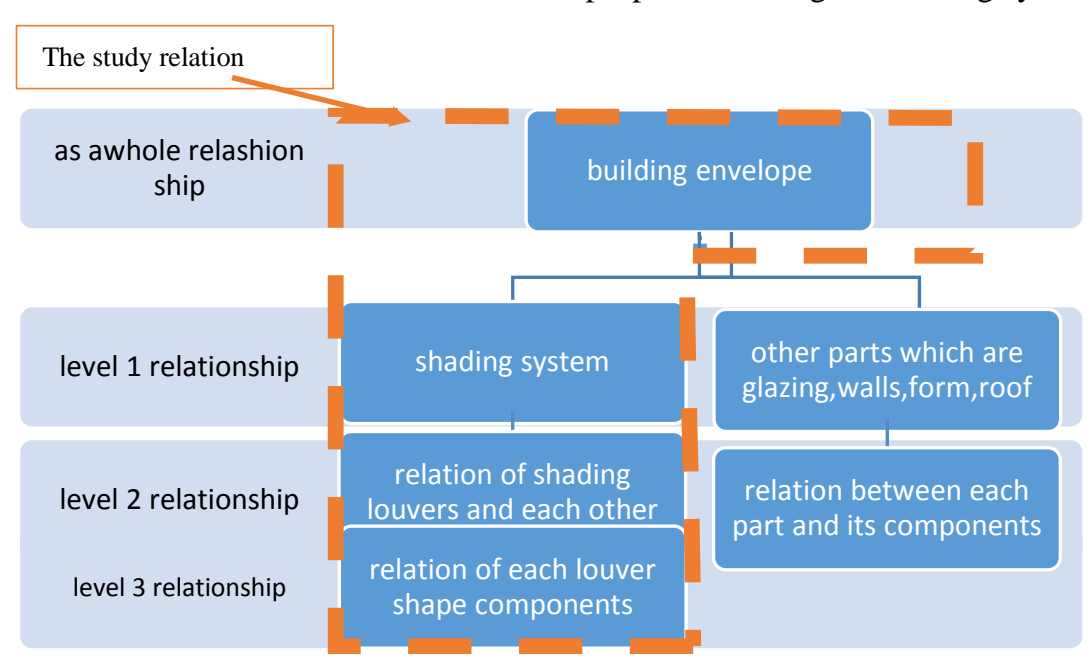

Figure 1: The case study analysis of the achievement of the alexandrine properties on three levels of relations for shading system components (by researcher)

Table 1 : Evaluation checkpoints( by the researcher)

\begin{tabular}{|c|c|c|c|c|c|c|}
\hline element & \multicolumn{5}{|c|}{ sub-element } & Checkpoint \\
\hline sustainability & \multicolumn{5}{|c|}{ total score } & $\begin{array}{l}\text { Obtained from the } \\
\text { scorecard }\end{array}$ \\
\hline \multirow{3}{*}{$\begin{array}{c}\text { The fifteen properties } \\
\text { achievement level1, level2, } \\
\text { level } 3\end{array}$} & $\begin{array}{l}\text { Levels of } \\
\text { scale }\end{array}$ & Alt.repetation & $\begin{array}{c}\text { Local } \\
\text { symmetries }\end{array}$ & $\begin{array}{c}\text { Graded } \\
\text { variation }\end{array}$ & The void & \multirow{3}{*}{$\begin{array}{l}\text { Analyzed from the } \\
\text { building envelope }\end{array}$} \\
\hline & $\begin{array}{l}\text { Strong } \\
\text { center }\end{array}$ & $\begin{array}{l}\text { Positive } \\
\text { space }\end{array}$ & $\begin{array}{c}\text { Deep } \\
\text { interlock }\end{array}$ & roughness & Inner calm & \\
\hline & Boundaries & Good shape & contrast & echoes & $\begin{array}{c}\text { Not- } \\
\text { separateness }\end{array}$ & \\
\hline
\end{tabular}


Table 2: Selected case studies general information(by the researcher based on [13],[16])

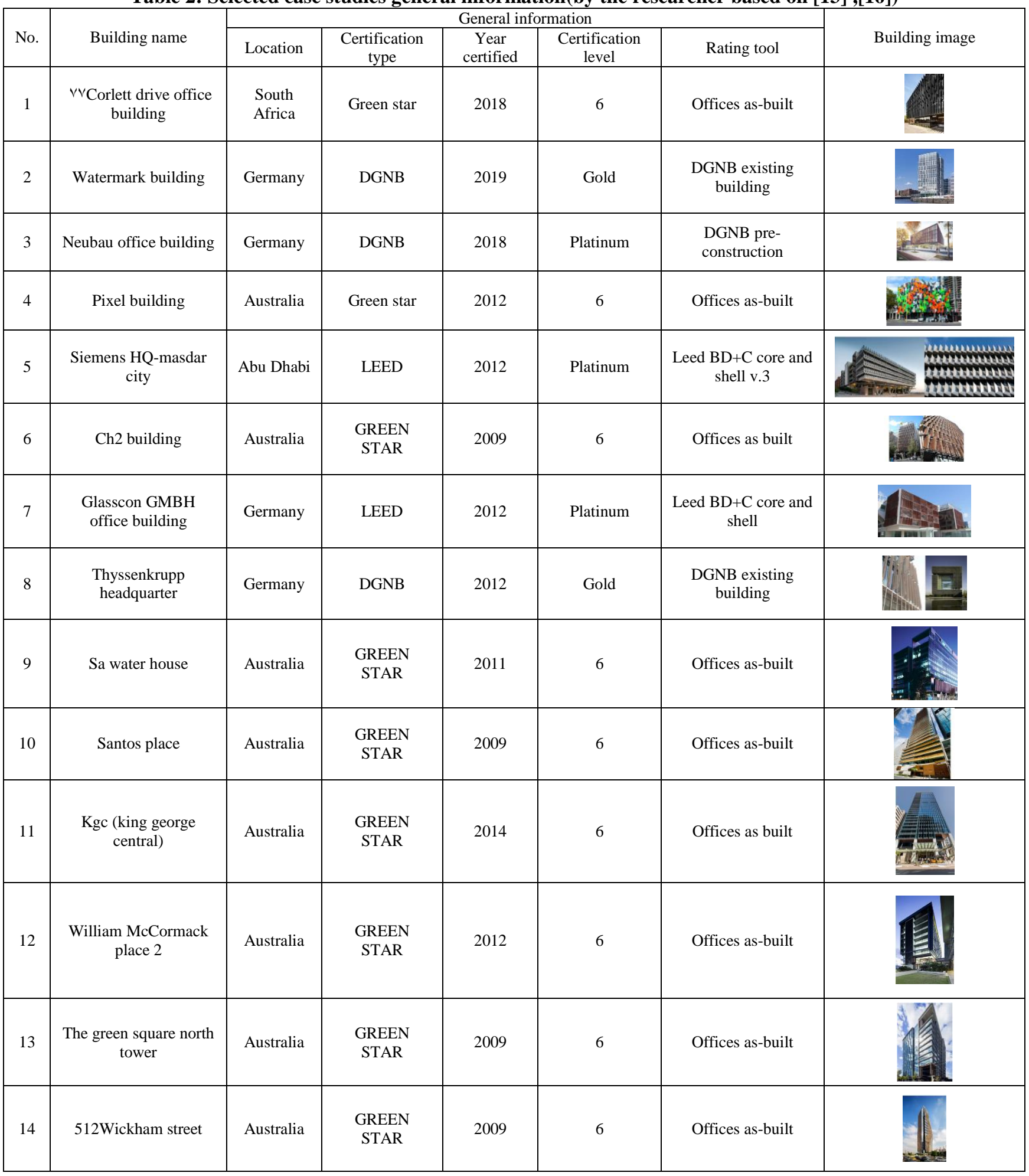


Table 2( Continued): selected case studies general information(by the researcher based on [13],[16])

\begin{tabular}{|c|c|c|c|c|c|c|c|}
\hline \multirow[b]{2}{*}{ No. } & \multirow[b]{2}{*}{ Building name } & \multicolumn{5}{|c|}{ General information } & \multirow[b]{2}{*}{ Building image } \\
\hline & & Location & $\begin{array}{c}\text { Certification } \\
\text { type }\end{array}$ & $\begin{array}{c}\text { Year } \\
\text { certified }\end{array}$ & $\begin{array}{c}\text { Certification } \\
\text { level }\end{array}$ & Rating tool & \\
\hline 15 & $\begin{array}{c}\text { Maroochydore } \\
\text { government office } \\
\text { building }\end{array}$ & Australia & Green star & 2012 & 6 & Offices as-built & \\
\hline 16 & $\begin{array}{c}\text { The gauge, } 825 \text { Bourke } \\
\text { street }\end{array}$ & Australia & Green star & 2008 & 6 & Offices as-built & \\
\hline 17 & 150 Collins street & Australia & Green star & 2016 & 6 & Offices as-built & \\
\hline 18 & $\begin{array}{l}\text { Cola place, } 16-40 \text { mount } \\
\text { street, North Sydney }\end{array}$ & Australia & Green star & 2014 & 6 & Offices as-built & \\
\hline 19 & 85 Castlereagh street & Australia & Green star & 2014 & 6 & Offices as-built & \\
\hline 20 & Liberty place & Australia & Green star & 2014 & 6 & Offices as-built & \\
\hline 21 & 8 chiefly & Australia & Green star & 2015 & 6 & Offices as-built & \\
\hline 22 & 5 Murray rose avenue & Australia & Green star & 2014 & 6 & Offices as-built & \\
\hline 23 & $\begin{array}{c}400 \text { George Street, } \\
\text { Brisbane }\end{array}$ & Australia & Green star & 2011 & 5 & Offices as-built & \\
\hline 24 & Media house & Australia & Green star & 2011 & 5 & Offices as-built & \\
\hline 25 & 1 Collins square & Australia & Green star & 2014 & 5 & Offices as-built & \\
\hline 26 & Bloomberg Hq & Uk & BREEAM & 2014 & Outstanding & New construction & \\
\hline 27 & $\begin{array}{c}\text { Coronation drive office } \\
\text { park building } 4\end{array}$ & Australia & GREEN STAR & 2010 & 5 & Offices as-built & \\
\hline 28 & $\begin{array}{l}\text { Van ness medical office } \\
\text { building }\end{array}$ & $\begin{array}{l}\text { California, } \\
\text { US }\end{array}$ & LEED & 2019 & Gold & $\begin{array}{c}\text { Leed } 2009 \text { core } \\
\text { and shell }\end{array}$ & \\
\hline 29 & $\begin{array}{c}\text { Office building expo } 2000 \\
\text { - phase iv }\end{array}$ & Bulgaria & LEED & 2018 & Platinum & $\begin{array}{l}\text { Leed v4 for } \mathrm{BD}+\mathrm{C} \text { : } \\
\text { core and shell }\end{array}$ & \\
\hline 30 & Porto office a & Poland & LEED & 2019 & Gold & $\begin{array}{l}\text { Leed v4 for BD+C: } \\
\text { core and shell }\end{array}$ & \\
\hline
\end{tabular}




\section{ReSUltS AND DiscuSSIONS}

Through the previous study, several important notes can be concluded by analyzing the effect of the alexandrine rule usage on building sustainability see Table 4 . The analysis results are described in the following points:

\subsection{Sustainability Evaluation}

Twenty-three percent (23\%) of the selected case studies achieve sustainability with a score less than $60 \%$, Fifty percent $(50 \%)$ of the case studies achieve sustainability with a score from (60\% to $70 \%$ ), Twenty-six percent (26\%) of the case studies achieve sustainability with a score over 70 \%. (as shown in Figure 2).

\subsection{Alexandrine Rules Evaluation}

The analysis of the case studies for the achievement of the alexandrine rules found that only $16 \%$ of the case studies tend to achieve the alexandrine rules with a percentage more than $50 \%, 83 \%$ of the selected case studies achieves the alexandrine rules with ratios from ( $0 \%$ to $50 \%$ ) as shown in Figure 3. On the other hand, the fifteen rules repetition among the case studies varied from zero to 80 times appearance as shown in Table3. The relation between each rule repetition and the building sustainability is analyzed and found its correlation which showed a positively weak linear correlation between sustainability ratio and the rules: boundaries, deep interlock, roughness, echoes and not separateness. The analysis shows a moderate positive linear correlation between the rule "contrast "and the sustainability ratio. The analysis also shows a weak negative linear correlation between the following rules and sustainability ratio "levels of scale, alternating repetition, positive space, local symmetry, graded variation, simplicity, and inner calm". As shown in Figure 4. The Pearson correlation of total alexandrine rule achievement and the building sustainability ratio is calculated, the result is that the two variables have a linear correlation with the value of 0.07 , and this means that there is a very weak positive linear relationship via a shaky linear rule between the alexandrine rule total achievement and the sustainability ratio in office building shading system design a shown in Figure 5. The relation is weed due to the lack of using the alexandrine rules in contemporary architecture

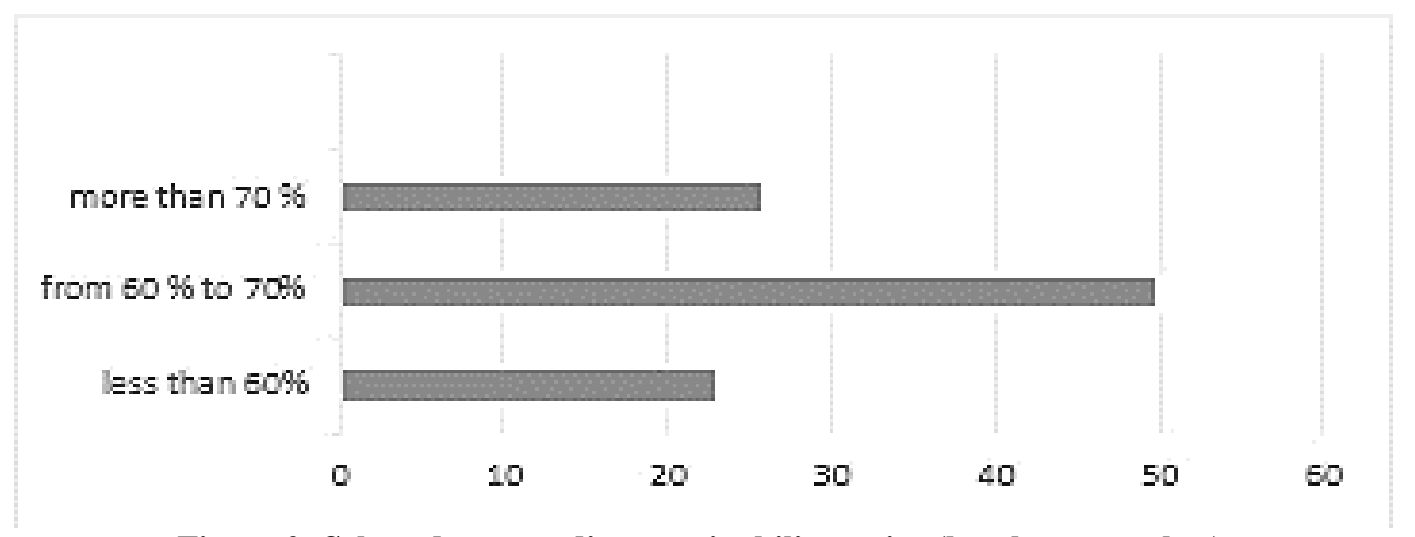

Figure 2: Selected case studies sustainability ratios (by the researcher)

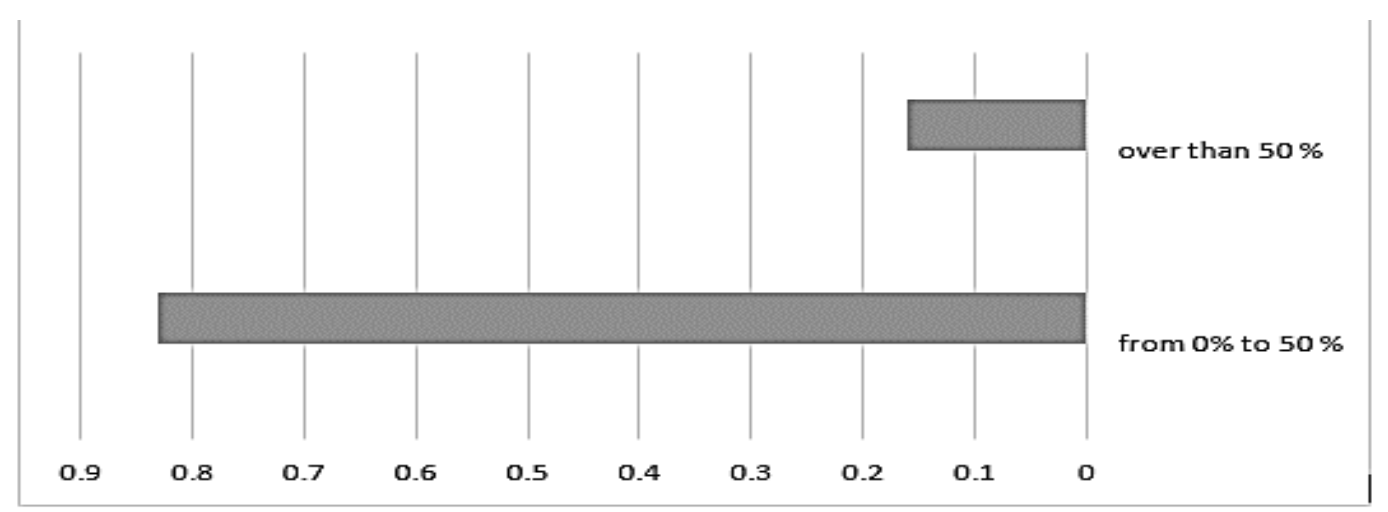

Figure 3: The Alexandrine rule achievement percentage among selected case studies.( by the researcher) 
Table 3: Repetition number of each rule among the selected case studies ( by the researcher)

\begin{tabular}{|c|c|c|c|}
\hline Rule name & $\begin{array}{c}\text { Number of } \\
\text { repetitions }\end{array}$ & Rule name & $\begin{array}{c}\text { Number of } \\
\text { repetitions }\end{array}$ \\
\hline Levels of scale & 21 & Deep interlock & 30 \\
\hline Strong center & 0 & contrast & 41 \\
\hline Boundaries & 36 & Graded variation & 8 \\
\hline Alternating repetition & 22 & roughness & 7 \\
\hline Positive space & 64 & echoes & 41 \\
\hline Good shape & 63 & The void & 8 \\
\hline Local symmetry & 78 & $\begin{array}{c}\text { Simplicity and } \\
\text { inner calm }\end{array}$ \\
\hline \multicolumn{2}{|c|}{ Not separateness } & & 57 \\
\hline
\end{tabular}

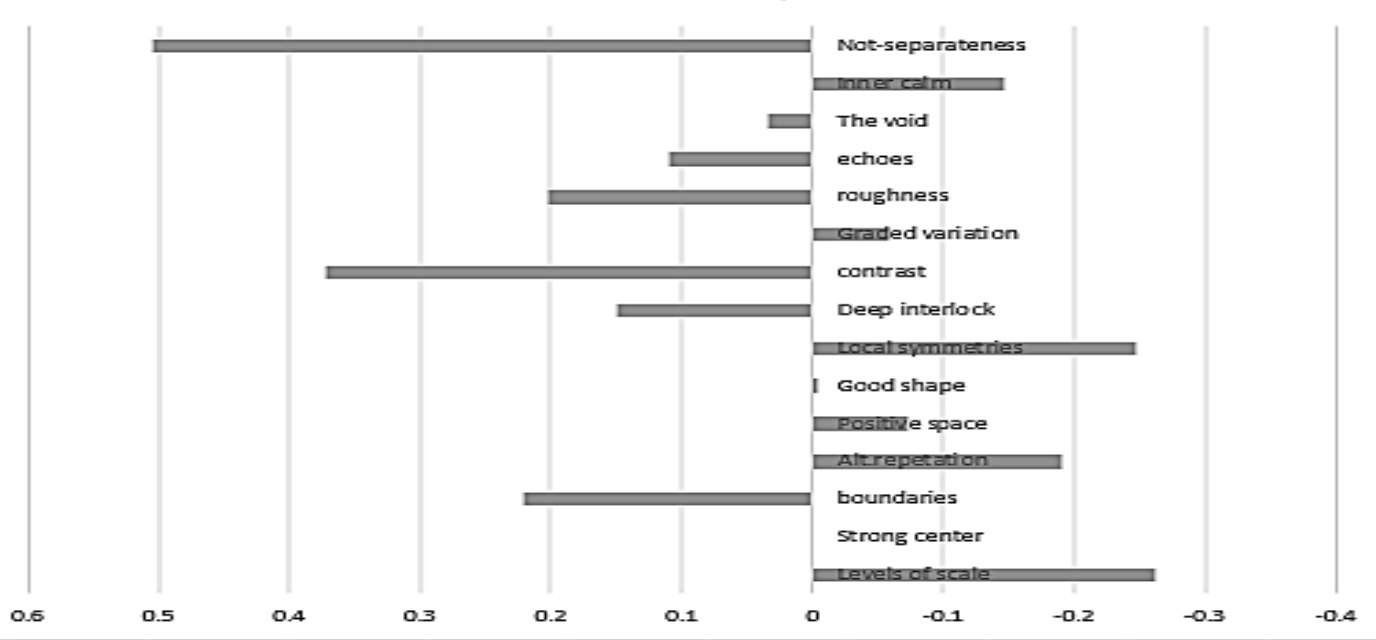

Figure 4: Correlation value between each alexandrine rule repetition score and building sustainability ratio

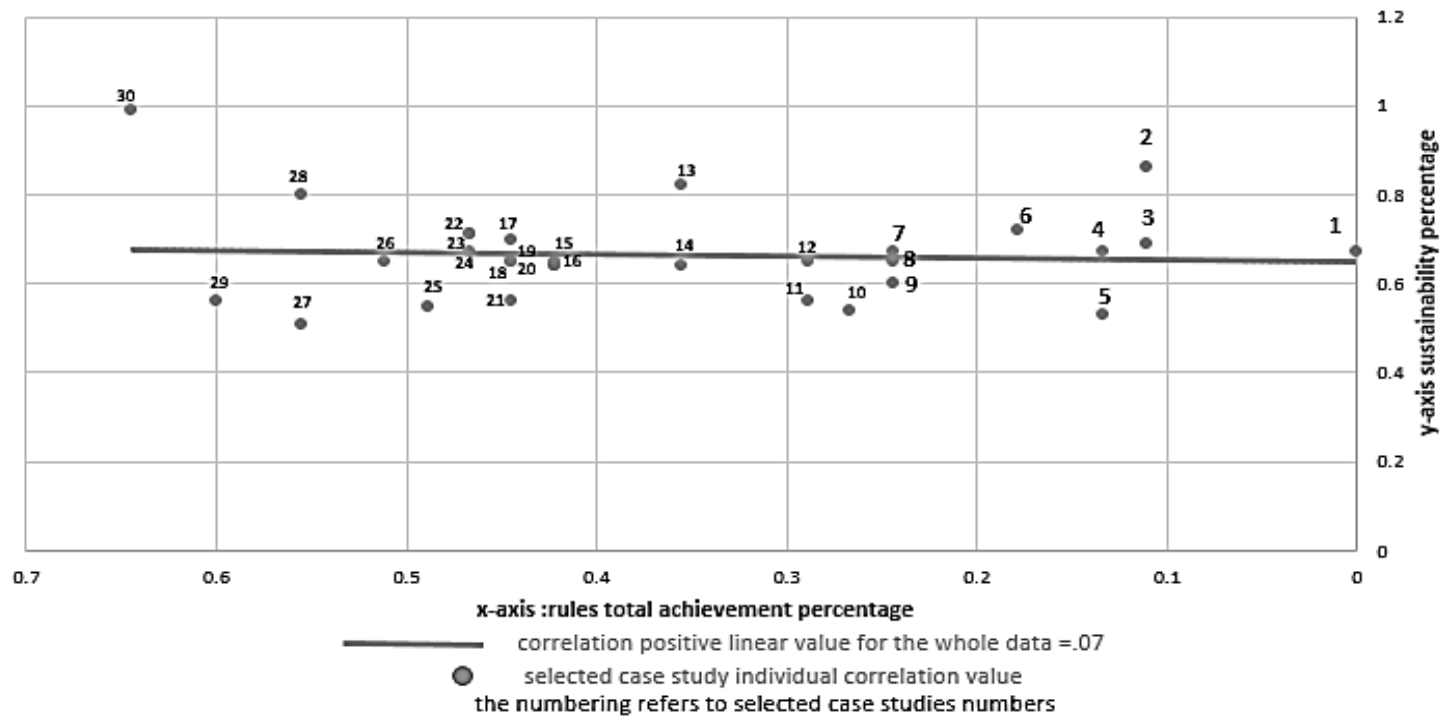

Figure 5: Correlation graph showing week positive linear relationship between the total achievement percentage of Alexandrine rules and the sustainability percentage 
Table 4: The case studies shading system achievement score on three levels of relations analysis and sustainability score.

\begin{tabular}{|c|c|c|c|c|c|c|}
\hline & & & & & & \\
\hline No & BUILDING NAME & 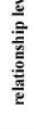 & 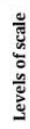 & 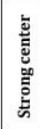 & 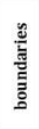 & 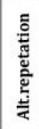 \\
\hline & & A & 1 & 0 & 0 & 1 \\
\hline 1 & 77 corlett drive office building & B & 1 & 0 & 0 & 1 \\
\hline & & C & 1 & 0 & 0 & 0 \\
\hline & & A & 0 & 0 & 0 & 1 \\
\hline 2 & watermark building & B & 0 & 0 & 1 & 1 \\
\hline & & C & 0 & 0 & 0 & 0 \\
\hline & & A & 0 & 0 & 1 & 0 \\
\hline 3 & doc1 mainz & в & 0 & 0 & 0 & 0 \\
\hline & & c & 0 & 0 & 1 & 0 \\
\hline & & A & 0 & 0 & 0 & 0 \\
\hline 4 & PIXEL BUILDING & B & 0 & 0 & 0 & 0 \\
\hline & & c & 0 & 0 & 0 & 0 \\
\hline & & A & 0 & 0 & 0 & 0 \\
\hline 5 & SIEMENS HQ-masdar city & в & 0 & 0 & 0 & 0 \\
\hline & & c & 1 & 0 & 0 & 0 \\
\hline & & A & 0 & 0 & 1 & 1 \\
\hline 6 & ch2 building & B & 0 & 0 & 0 & 1 \\
\hline & & $\mathrm{c}$ & 1 & 0 & 0 & 0 \\
\hline & & A & 0 & 0 & 1 & 1 \\
\hline 7 & glasscon gmbh office building & B & 0 & 0 & 1 & 0 \\
\hline & & c & 0 & 0 & 0 & 0 \\
\hline & & A & 0 & 0 & 1 & 1 \\
\hline 8 & ThyssenKrupp Headquarter & B & 0 & 0 & 0 & 1 \\
\hline & & $\mathrm{C}$ & 0 & 0 & 1 & 0 \\
\hline & & A & 0 & 0 & 1 & 0 \\
\hline 9 & SA Water House & B & 0 & 0 & 1 & 0 \\
\hline & & c & 0 & 0 & 0 & 0 \\
\hline & & A & 0 & 0 & 0 & 0 \\
\hline 10 & Santos Place & B & 0 & 0 & 0 & 0 \\
\hline & & $\mathrm{C}$ & 0 & 0 & 0 & 0 \\
\hline & & A & 1 & 0 & 1 & 0 \\
\hline 11 & KGC (King George Central) & B & 1 & 0 & 0 & 1 \\
\hline & & c & 0 & 0 & 0 & 0 \\
\hline & & A & 0 & 0 & 1 & 0 \\
\hline 12 & William McCormack Place 2 & B & 1 & 0 & 1 & 0 \\
\hline & & C & 0 & 0 & 0 & 0 \\
\hline & & A & 0 & 0 & 1 & 0 \\
\hline 13 & Green Square North Tower & в & 0 & 0 & 1 & 1 \\
\hline & & c & 0 & 0 & 0 & 0 \\
\hline & & A & 1 & 0 & 1 & 0 \\
\hline 14 & Ronesans Tower Office Building & B & 1 & 0 & 1 & 1 \\
\hline & & C & 0 & 0 & 0 & 0 \\
\hline & & A & 0 & 0 & 1 & 0 \\
\hline 15 & Maroochydore Government Office Building & в & 0 & 0 & 0 & 0 \\
\hline & & c & 0 & 0 & 1 & 0 \\
\hline & & A & 0 & 0 & 0 & 0 \\
\hline 16 & The Gauge, 825 Bourke Street & B & 0 & 0 & 0 & 0 \\
\hline & & c & 0 & 0 & 0 & 0 \\
\hline & & A & 0 & 0 & 0 & 0 \\
\hline 17 & 150 Collins Street & в & 0 & 0 & 0 & 0 \\
\hline & & c & 0 & 0 & 0 & 0 \\
\hline & & A & 0 & 0 & 0 & 0 \\
\hline 18 & Cola Cola Place, $16-40$ Mount Street, North & B & 0 & 0 & 0 & 0 \\
\hline & & c & 0 & 0 & 0 & 0 \\
\hline & & A & 0 & 0 & 0 & 0 \\
\hline 19 & 85 Castlereagh Street & В & 1 & 0 & 0 & 1 \\
\hline & & c & 0 & 0 & 0 & 0 \\
\hline & & A & 0 & 0 & 1 & 0 \\
\hline 20 & Liberty Place & B & 0 & 0 & 1 & 0 \\
\hline & & c & 0 & 0 & 0 & 0 \\
\hline & & A & 1 & 0 & 0 & 0 \\
\hline 21 & 8 Chifley & B & 1 & 0 & 1 & 0 \\
\hline & & c & 0 & 0 & 0 & 0 \\
\hline & & A & 0 & 0 & 1 & 0 \\
\hline 22 & 5 Murray Rose Avenue & B & 0 & 0 & 0 & 0 \\
\hline & & c & 0 & 0 & 0 & 0 \\
\hline & & A & 1 & 0 & 1 & 1 \\
\hline 23 & 400 George Street, Brisbane & B & 1 & 0 & 1 & 1 \\
\hline & & c & 0 & 0 & 0 & 0 \\
\hline & & A & 0 & 0 & 0 & 0 \\
\hline 24 & Media House & B & 0 & 0 & 0 & 1 \\
\hline & & C & 0 & 0 & 0 & 0 \\
\hline & & A & 1 & 0 & 0 & 0 \\
\hline 25 & 1 Collins Square & в & 0 & 0 & 0 & 0 \\
\hline & & $\mathrm{c}$ & 0 & 0 & 0 & 0 \\
\hline & & A & 1 & 0 & 1 & 0 \\
\hline & BLOOMBERG HQ & B & 0 & 0 & 1 & 0 \\
\hline 26 & & c & 0 & 0 & 1 & 0 \\
\hline & & A & 1 & 0 & 1 & 1 \\
\hline 27 & Coronation Drive Office Park Building 4 & в & 1 & 0 & 1 & 1 \\
\hline & & $\mathrm{C}$ & 0 & 0 & 0 & 1 \\
\hline & & A & 0 & 0 & 1 & 0 \\
\hline 28 & Van Ness Medical Office Building & B & 1 & 0 & 1 & 1 \\
\hline & & c & 1 & 0 & 0 & 0 \\
\hline & & A & 0 & 0 & 1 & 1 \\
\hline 29 & Office Building Expo 2000 - Phase IV & B & 0 & 0 & 1 & 1 \\
\hline & & c & 0 & 0 & 1 & 0 \\
\hline & & A & 0 & 0 & 1 & 0 \\
\hline 30 & Porto Office A & B & 0 & 0 & 0 & 0 \\
\hline & & $\mathrm{C}$ & 0 & 0 & 0 & 0 \\
\hline
\end{tabular}




\section{Conclusion}

This study investigates the relation between using alexander's fifteen fundamental properties and the building's sustainability. The investigation is done by analyzing the office building shading system for 30 case studies. The analysis compares the achievement percentage of each rule on the three levels of relation and the sustainability score of selected certified case studies. These buildings have a clear usage of the shading system in facade design. As a result, the analysis found that there is a certain relation between each alexandrine rule and the sustainability of selected case studies. There is also a linear positive weak relationship between the total rule achievement score and the sustainability of selected case studies. The relation is weak due to the lack of using the rules in the shading system's design. Therefore, the relation would become stronger by using more rules in the design process. Finally, a strong relation will lead to a more psychologically comfortable building.

\section{Credit Authorship Contribution Statement}

Osama M. Abo Eleinen: methodology, supervision; Dina Samy Noaman: methodology, validation, supervision, formal analysis, review and editing; Mayar El-sayed Moeat: conceptualization, formal analysis, investigation, resources, original draft.

\section{DECLARATION OF COMPETING INTEREST}

The authors declare that they have no known competing financial interests or personal relationships that could have appeared to influence the work reported in this paper.

\section{REFERENCES}

[1] C. Alexander, The timeless way of building.

[2] Christopher Alexander, Christopher Alexander'sThe Nature of Order: An Essay on the Art of Building and the Nature of the Universe, book 1.

[3] Nikos salingaros, a, "The Legacy of Christopher Alexander: Form Language, Pattern Language, and Complexity," 2018.

[4] S. Mirrahimi, M. F. Mohamed, L. C. Haw, N. L. N. Ibrahim, W. F. M. Yusoff, and A. Aflaki, "The effect of building envelope on the thermal comfort and energy saving for high-rise buildings in a hot-humid climate," Renew. Sustain. Energy Rev., vol. 53, pp. 1508-1519, 2016, DOI: 10.1016/j.rser.2015.09.055.

[5] L. Bellia, F. De Falco, and F. Minichiello, "Effects of solar shading devices on energy requirements of standalone office buildings for Italian climates," Appl. Therm. Eng., vol. 54, no. 1, pp. 190-201, 2013, DOI: 10.1016/j.applthermaleng.2013.01.039.

[6] N. H. Wong and S. Li, "A study of the effectiveness of passive climate control in naturally ventilated residential buildings in Singapore," Build. Environ., vol. 42, no. 3, pp. 1395-1405, Mar. 2007, DOI: 10.1016/j.buildenv.2005.11.032.

[7] N. A. Al-Tamimi and S. F. S. Fadzil, "The potential of shading devices for temperature reduction in highrise residential buildings in the tropics," in Procedia
Engineering, 2011,
10.1016/j.proeng.2011.11.2015.

DOI:

8] S. Olson, "Baltimore: The building of an American city "' 1980.

[9] R. V. Ralegaonkar and R. Gupta, "Review of intelligent building construction: A passive solar architecture approach," Renewable and Sustainable Energy Reviews, vol. 14, no. 8. Pergamon, pp. 2238 2242, 01-Oct-2010, DOI: 10.1016/j.rser.2010.04.016.

[10]H. Leitner, "Pattern Theory: Introduction and Perspectives on the Tracks of Christopher Alexander.".

[11]C. Alexander, The nature of order: an essay on the art of building and the nature of the universe. Center for Environmental Structure, 2002.

[12] Nikos salingaros, a, "algorithmic sustainable design," 2012. [Online]. Available: http://zeta.math.utsa.edu/ yxk833/algorithmic.html.

[13] "Projects | U.S. Green Building Council." [Online]. Available:

https://www.usgbc.org/projects?Rating+System $=\% 5$ B\%22LEED BD\%2BC: Core and Shell\%22\%5D. [Accessed: 29-Feb-2020].

[14] "DGNB pre-certified and certified projects." [Online]. Available: https://www.dgnbsystem.de/en/projects/. [Accessed: 29-Feb-2020].

[15] "BREEAM: the world's leading sustainability assessment method for master-planning projects, infrastructure, and buildings - BREEAM." [Online]. Available: https://www.breeam.com/. [Accessed: 29Feb-2020].

[16] "Green Star Project Directory - Green Building Council Australia (GBCA)." [Online]. Available: https://www.gbca.org.au/project-directory.asp. [Accessed: 29-Feb-2020]. 